CARADDE: Jurnal Pengabdian Kepada Masyarakat
$\begin{gathered}\text { https://journal.ilininstitute.com/index.php/caradde } \\ \text { Volume 1 | Nomor 1 | Agustus | } 2018 \\ \text { e-ISSN: 2621-7910 dan p-ISSN: } 2621-7961 \\ \text { DOI: } \text { https://doi.org/10.31960/caradde.v1i1.13 }\end{gathered}$

\title{
Program Pengembangan Kewirausahaaan Fakultas Keguruan Dan Ilmu Pendidikan
}

\author{
Ma'rufi $^{1}$, Muhammad Ilyas ${ }^{2}$, Aswar Anas ${ }^{3}$, Reski Yusrini Islamiah ${ }^{4}$
}

\begin{tabular}{|c|c|}
\hline $\begin{array}{l}\text { Corespondensi Author } \\
\text { Pendidikan Matematika, } \\
\text { Universitas Cokroaminoto } \\
\text { Palopo } \\
\text { BTN Nyiur Jalan Sulawesi } 14 \\
\text { No.1 } \\
\text { Email: marufi.ilyas@gmail.com }\end{array}$ & $\begin{array}{l}\text { Abstrak. Tujuan program pengembangan kewirausahaan } \\
\text { iultas Keguruan dan Ilmu Pendidikan adalah menghasilkan } \\
\text { hasiswa dan alumni berwirausaha yang mandiri berbasis iptek, } \\
\text { !alui program yang terintegrasi dengan melibatkan dosen, } \\
\text { asumber, mahasiswa, dan alumni. Kegiatan program ini antara } \\
\text { l (1) pengembangan jiwa wirausaha, (2) pelatihan manajemen dan } \\
\text { 'ls usaha bagi tenant, (3) konsultasi bisnis, dan (4) memfasilitasi } \\
\text { ant dalam berwirausaha untuk menghasilkan wirausaha baru. } \\
\text { atihan manajemen kewirausahaan berbasis kemandirian } \\
\text { lksanakan untuk memberikan pengetahuan kewirausahaan, } \\
\text { ndorong tumbuhnya motivasi berwirausaha, meningkatkan } \\
\text { zahaman manajemen organisasi, manajemen produksi, manajemen } \\
\text { angan, dan manajemen pemasaran, serta membuat rencana bisnis } \\
\text { u studi kelayakan usaha. Bebarapa tenant mengikuti magang pada } \\
\text { t usaha mitra untuk memberikan pengalaman praktis } \\
\text { irausahaan kepada mahasiswa dan alumni dengan cara ikut } \\
\text { erja sehari-hari pada unit usaha tersebut. Mahasiswa dan alumni } \\
\text { ig berminat atau baru merintis usaha bisa menyempurnakan } \\
\text { iatan kewirausahaan yang telah dilakukan sebelumnya. Tim } \\
\text { gelola program ini yaitu mahasiswa dan alumni, menggali jenis } \\
\text { noditas bisnis para tenant sesuai dengan bakat dan minatnya. } \\
\text { hun 2018 program ini melakukan pembinaan kewirausahaan } \\
\text { ada lebih dari } 20 \text { tenant mahasiswa dan alumni yang merintis } \\
\text { ha baru, selanjutnya dari jumlah tersebut dipilih } 20 \text { orang menjadi } \\
\text { ant. Di akhir program ini menghasilkan } 5 \text { tenant mahasiswa dan } \\
\text { mni menjadi wirausaha baru dengan berbagai bidang usaha yang } \\
\text { dimensi "Inovasi Kreasi Bisnis yang Mengsinergikan Dunia Usaha } \\
\text { gan Dunia Pendidikan Menggunakan Teknik Warung Pendidikan } \\
\text { ARPEN)". Bidang usaha antara lain: (1) Warpen Aksesoris, (2) } \\
\text { irpen Bimbel, (3) Warpen Literasi, (4) Warpen Analisis Data } \\
\text { arpen Anda), dan (5) Warpen Desain. }\end{array}$ \\
\hline
\end{tabular}

(i) This work is licensed under a Creative Commons Attribution 4.0 International License

\section{PENDAHULUAN}

Universitas Cokroaminoto Palopo (UNCP) terdapat lima fakultas yaitu Fakultas Keguruan dan Ilmu Pendidikan (FKIP),
Fakultas Sains, Fakultas Teknik Informatika, dan Fakultas Pertanian. Saat ini, fakultas yang terbanyak mahasiswanya adalah FKIP dengan 6 program studi. Sejak tahun 2010, kegiatan PKM di Universitas Cokroaminoto 
Palopo mengalami perkembangan yang cukup pesat hal ini terlihat dari peningkatan jumlah proposal yang didanai oleh Dikti, bahkan untuk tahun 2016, mahasiswa FKIP juga berhasil menembus PIMNAS ke 29 di Bogor.

Ciri khas utama PKM Kewirausahaan yang banyak di FKIP adalah kewirausahaan yang berbasis pendidikan. Seperti wirausaha jasa analisis data peneltian, bimbingan belajar, jasa tour pariwisata dan budaya, konsultan pendidikan, dan komik lontara sebagai buku bacaan dan semua produk pendidikan tersebut mengandung nilai bisnis yang sangat menarik apabila dikembangkan khususnya untuk pendidikan.

Hasil dari produksi kewirausahaan mahasiswa di FKIP UNCP sangat potensial dan memiliki nilai jual yang cukup tinggi. Menurut Oki (2016) bahwa banyak hasil kewirausahaan mahasiswa memiliki keunikan serta nilai artistik karena tetap menampilkan nilai-nilai lokal filosofi Sulawesi Selatan dengan penampilan yang lebih modis dan modern. Dengan demikian usaha rintisan mahasiswa tersebut layak untuk dikembangkan sebagai wirausaha mandiri dan berkembang. Mahasiswa sebagai insan dewasa yang mandiri dapat mengembangkan potensinya melalui wirausaha sehingga dapat berjiwa entrepreneur dan memperoleh banyak manfaat dari wirausaha. Thomas (dalam Saragih, 2017) menjelaskan bahwa manfaat yang dapat diperoleh mahasiswa dalam berwirausaha antara lain memberi peluang dan kebebasan mengendalikan nasib sendiri, memberi peluang untuk mencapai potensi sepenuhnya, dan memberi peluang untuk berperan aktif dalam masyarakat dan mendapat pengakuan atas usahanya.

Kewirausahaan dapat dikatakan merupakan salah satu faktor penentu bagi kemajuan suatu Negara. Pertumbuhan ekonomi dapat dicapai jika negara memiliki banyak wirausaha. Menurut David McClelland, suatu negara untuk menjadi makmur minimum memiliki jumlah wirausaha $2 \%$ dari total jumlah penduduk contohnya seperti negara Amerika Serikat memiliki $11,5 \%$ wirausaha, Singapura terus meningkat menjadi 7,2 \%, Indonesia menurut data dari BPS (2010) diperkirakan hanya sebesar 0,18 \% (sekitar 400.000 dari yang seharusnya 4,4 juta). Dengan kata lain bahwa wirausaha adalah pelaku penting dari kegiatan ekonomi modern saat ini (Siswadi, 2014).

Sepanjang bulan Februari hingga Agustus 2014, jumlah pengangguran di Indonesia bertambah 0,09 juta orang dari 7,15 juta orang meningkat 7,24 juta orang. Dengan jumlah ini, tingkat ini diprediksi akan bertambah karena pertumbuhan ekonomi yang melambat di 5,01\%. Menurut Badan Pusat Statistik (BPS), jumlah angkatan kerja di Indonesia mencapai 121,87 juta orang, yang meningkat dari Agustus tahun 2013 sebesar 120,17 juta orang. Tetapi peningkatan ini juga terjadi pada tingkat pengangguran terbuka Februari hingga Agustus 2014 sebesar 5,70\% naik 5,94\% (Adhimursandi, 2016). Hal ini menjadi sosok yang menakutkan bagi mahasiswa, sekaligus menjadi dasar agar mahasiswa dapat melakukan upaya dalam menciptakan suatu usaha.

Kendala utama mahasiswa dalam berwirausaha adalah time manager, bagaimana mengatur waktu dengan baik karena pada prinsipnya bisnis harus berinteraksi dengan sistem (Mutia, 2014:4). Mahasiswa kurang disiplin dalam mengatur waktu antara kegiatan akademik dengan kegiatan usaha yang dikembangkan terutama banyaknya tugas kuliah yang harus diselesaikan. Disamping itu kurangnya rasa percaya diri dalam pemasaran produksi yang dihasilkan serta kurangnya kemampuan berinteraksi dengan khalayak ramai sehingga dalam membangun relasi masih sangat bingung karena kurangnya kemampuan komunikasi dalam bisnis, padahal dalam dunia bisnis pola kemitraan sangat berperang penting dalam kemajuan dunia usaha makro (Wanda M.Widyani, 2013).

Menurut Faltin (2001) bahwa faktor keberhasilan dari peluncuran suatu usaha baru dipengaruhi oleh ide kreasi dan pengembangannya dengan faktor-faktor lain (manusia dan sumber daya). Dalam kaitannya, bahwa inovasi tidak hanya berdampak pada kompetisi produk, dalam arti yang lebih luas mencakup permasalahan sosial, dan keberlanjutan produk pada pasar.

Semangat tinggi yang ditujukkan oleh mahasiswa melalui program-program usaha di FKIP Universitas Cokroaminoto Palopo, maka dibutukan kegiatan pendampingan 
Ma'rufi, Ilyas, Anas, Islamiah. Program Pengembangan

dalam memberikan pengetahuan kewirausahaan dan sistem manajemen bisnis yang moderen dan berdaya saing disamping program magang untuk menambah keterampilan berwirausaha bagi tenant yang dibina nantinya. Program konseling, pendampingan serta pembimbingan juga diperlukan untuk membantu tenant dalam menjalankan usaha serta program studi banding dan sarasehan dunia usaha dengan menghadirkan motivator dunia usaha yang sukses yang memiliki jejaring bisnis yang luas sehingga mahasiswa memiliki motivasi yang tinggi menjadi wirausaha baru yang mandiri dan memiliki kompetensi untuk bersaing didunia bisnis.

Target yang dicapai dalam program PPK di Fakultas Keguruan dan Ilmu Pendidikan sebagai berikut:

Pengembangan dan peningkatan pengetahuan keterampilan tenant dalam membuka bisnis (berwirausaha). (1) Menghasilkan lima wirausaha baru di FKIP yang mandiri dan berdaya saing berbasis Ipteks, (3) Merancang dan menciptakan model pelatihan kewirausahaan yang disesuaikan dengan kebutuhan tenant. (4) Mempublikasikan laporan program melalui seminar dan jurnal yang bereputasi secara nasional.

\section{METODE}

Pelaksanaan Program PPK di Fakultas Kegruan dan Ilmu Pendidikan Universitas Cokroaminoto Palopo adalah tenant yang dibina diambil dari mahasiswa FKIP yang melakukan kegiatan PKM Kewirausahaan dan kegiatan kewirausahaan lainnya, serta alumni FKIP yang sedang menjalankan usaha.

Metode ysng digunakan dalam pelatihan kewirausahaan ini melalui tatap muka, dimana narasumber menjelaskan tentang mengembangkan semangat berwirausaha, pemberian bantuan berupa peralatan yang sesuai dengan usaha yang dirintis, membangun pendidikan berbasis kewirausahaan, pengembangan ide usaha, strategi menangkap peluang usaha, penyusunan rencana usaha, pemahaman resiko usaha, strategi mencapai keunggulan bersaing, pengelolaan usaha dan strategi kewirausahaan, teknik pengembangan usaha. Agar pelatihan aktif maka dilakukan diskusi kelompok, dimana tenant dibagi dalam kelompok yang memiliki usaha serupa atau sejenis, antara lain kelompok usaha perdagangan. Dalam diskusi ini tenant didampingi oleh narasumber dan dosen kewirausahaan agar tenant berani mengemukakan pendapatnya dan mendorong untuk berpikir inovatif.

Pola pembimbingan yang diterapkan pada pelayanan dan pendampingan wirausaha pada program PPK FKIP UNCP telah disusun secara terstruktur dsn berkesinambungan dengan metode coaching NLP (Neuro Linguistic Program). Dalam metode ini akan mengidentifikasikan kondisi awal usaha peserta dengan membagi masalah usaha tenant menjadi lima masalah yang lebih spesifik yaitu profil usaha, profil produk, pemasaran, pembukuan, bisnis plan teknik pengembangan usaha, resiko usaha, strategi mencapai keunggulan bersaing. Metode ini dilakukan dengan cara melakukan focus group discussion antara tenant, dosen pengampu mata kuliah kewirausahaan dan praktisi serta berupaya menggali kekuatan sumber daya internal dan eksternal tenant masing-masing.

Pola yang dilaksakan dalam pengawasan dalam bentuk controlling sehingga capaian tenant dalam berwirausaha sesuai dengan luaran yang diharapkan. Pengawasan ini dilaksanakan secara acak (minimal sekali dalam seminggu) sehingga bentuk data yang diperoleh sesuai dengan keadaan tenant. Apabila ditemukan kasus seperti tenant yang tidak berjalan dengan baik maka akan segera dilakukan pembinaan agar pola kewirausahaan yang dilaksanakan oleh tenant dapat berjalan dengan baik sesuai yang diharapkan.

Untuk mendukung program kewirausahaan yang dijalankan oleh tenant, diperlukan teknik pembiayaan atau permodalan secara professional dan tepat guna. Sumber pembiayaan dimanfaatkan oleh tenant melaui program PPK di FKIP adalah melalui PPK sendiri, perguran tinggi, perbankan, mitra usaha, dan lembaga pemberi kredit usaha. Karena sumber dana dalam bentuk kredit, secara otomatis tenant harus mengembalikan modal tersebut nantinya dengan teknik berangsur atau hasil produksi tenant dijual kepada mitra yang sudah disepakati harganya dan bantuan pembiayaan yang diperoleh dipotong dari hasil penjualan, atau berdasarkan kesepakatan 
Caradde: Jurnal Pengabdian Kepada Masyarakat

Vol 1 No 1, Agustus 2018

antara tenant dengan pihak lain pemberi pinjaman.

Pola pemberian teknologi dilaksanakan melaui workshop dan pelatihan khusus yang difasilitasi oleh tim PPK FKIP, Universitas Cokroaminoto Palopo, dan mitra usaha. Pemberian teknologi seperti teknologi produksi, pengemasan, advertising dan pemasaran. Pemberian teknologi juga dapat melalui institusi, pihak lain dan mitra usaha dengan skema hasil produksi tenant dijual kepada mitra dengan harga yang disepakati. Biaya bantuan teknologi dipotong dari hasil penjualan atau dalam bentuk skema yang lain.

\section{HASIL DAN PEMBAHASAN}

\section{Keunggulan Iptek Jasa/Produk Tenant}

Warung Pendidikan (Warpen)

memiliki keunggulan iptek, jasa yang secara operasional dan professional yang diselenggarakan melalui berbagai kegiatan sehingga menjadi wadah yang sangat dibutuhkan masyarakat. Kegiatan yang sangat penting dan diminati para orang tua untuk memasukkan anak-anaknya utnuk mengikuti bimbingan belajar melalui warpen bimbel, warpen senam, dan warpen literasi. Demikian juga, mahasiswa sangat antusias melalui warpen aksesoris, warpen bimbel, warpen anda, warpen desain, dan warpen literasi. Selempang dan bunga yudisiun berbasis iptek laris manis, dimana selempang yang dirancang model dengan motif menarik yang dipakai pada saat yudisiun. Bunga sebagai symbol ucapan selamat atau kesuksesan meraih kesajarnaan di kampus sangat diburu sarjana dan keluarganya.

Program PPK FKIP UNCP 2018 menghasilkan sebanyak 20 tenant wirausaha baru, baik tenant merintis usaha maupun tenant wirausaha baru. Wirausaha baru ini sebagai calon yang akan dilatih melalui program terintegrasi dengan kreativitas, baik secara internal maupun eksternal dalam rangka menjadi wirausaha mandiri pada tahun 2018. Mahasiswa yang merintis usaha sebanyak 6 mahasiswa, sedangkan mahasiswa yang berwirausaha baru sebanyak 14 mahasiswa. Mahasiswa tersebut diharapkan memiliki motivasi tinggi untuk memperoleh pengalaman berusaha dan berpikir kreatif memahami secara konperehensif ilmu pengetahuan dan teknologi dalam mengembangkan dan memberdayakan potensi dan keunggulan mereka menciptakan berbagai kesempatan dan peluang usaha jasa dan bisnis yang begitu trend saat ini.

UNCP menyelenggarakan pameran produk mahasiswa dan alumni yang memfasilitasi mahasiswa dan alumni dalam meningkatkan manajemen produksi, pemasaran, keuangan, dan organisasi. Selain itu, meningkatkan kemampuan mahasiswa dan alumni membuat rencana bisnis atau studi kelayakan usaha. Keikutsertaan mahasiswa dan alumni dalam pameran untuk memberikan kesempatan dan pengalaman praktis kewirausahaan. Dengan demikian, mahasiswa dapat menunjukkan permulaan berwirausaha yang sedang merintis usaha, dan alumni yang berminat atau baru merintis usaha dapat menyempurnakan kegiatan kewirausahaan yang telah dilakukan sebelumnya untuk meningkatkan usahanya.

\section{Potensi dan Nilai Ekonomi Usaha Tenant} FKIP UNCP

\section{Warung Pendidikan (WARPEN) Asesoris}

Tenant merintis usaha salempang yudisium yang merupakan salah satu produk yang dijalankan atau difasilitasi pada jenis usaha/galeri warung pendidikan aksesoris (WARPEN Aksesoris). Pada awalnya pemakaian salempang dengan nama yudisium belum populer dikalangan para calon sarjana, masih kadang-kadang belum terlihat atau masih dihitung jari yang mengenakan salempang di saat adanya acara yudisium. Pemakaian salempang yang sangat jarang dan masih langkah ini baru diusahakan dengan inisiatif sendiri-sendiri oleh calon sarjana, belum diproduksi secara kolektif oleh wira usaha. 
Ma'rufi, Ilyas, Anas, Islamiah. Program Pengembangan

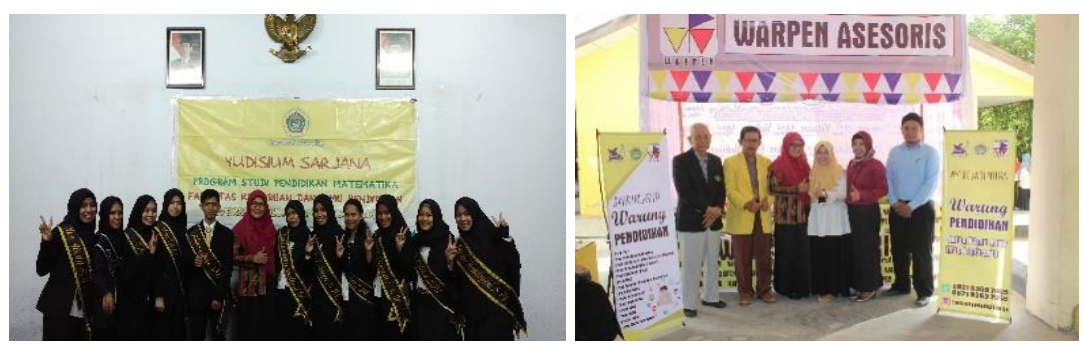

Gambar 1: Selempang Yudisium dan Bucket Bunga

Bisnis tenant Cantika yang dirintis kini sedang trend dengan nama paper flower yang diwadahi dari Warpen Aksesoris Program PPK FKIP UNCP, bisa menghasilkan omzet bisnis yang menggembirakan. Angka yang cukup untuk bisnis bunga kertas produksi rumahan dan kosan. Kebutuhan bunga ini dikalangan mahasiswa semakin menggeliat bagi yang ingin tampak berbeda ketika menyambut ultah, yudisium, wisuda, ramatamah, dan lain-lain. Agar produksi dan omzet optimal bersama dengan label Warpen Aksesoris mengunggah ke akun Instagram dan promosi. Sentuhan yang berkembang dari produknya, maka jenis produk dan paketnya bervariasi. Paper flowers menyuguhkan dekorasi, foto booth, dan hand bouqet bunga artifisial.
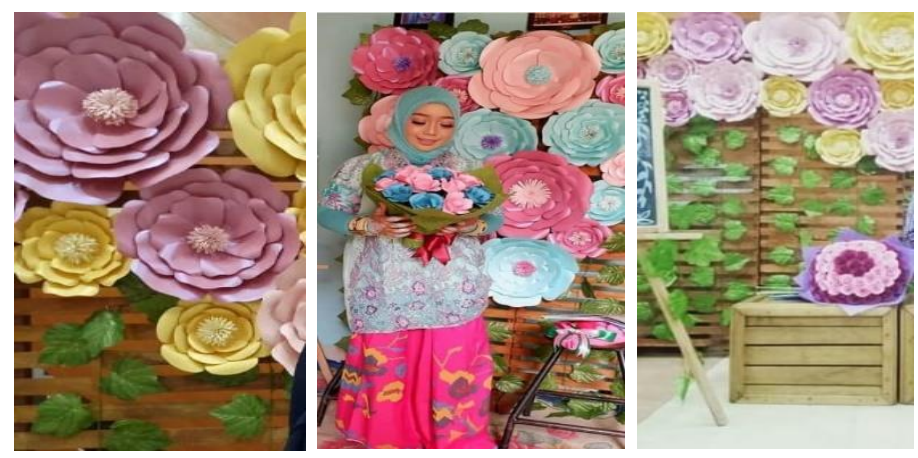

Gambar 2: Paper Flowers "Rumah Cantik

Bisnis kreatif pembuatan boneka wisuda "Fisma Art," program PPK FKIP UNCP memiliki potensi dapat menjadi wirausaha baru yang menjanjikan dikalangan mahasiswa dan alumni. Salah satu bentuk kreativitas tangan tenant program PPK FKIP UNCP dalam membuat boneka wisuda. Bentuk boneka wisuda yang dihasilkan tenant masih lebih sederhana dan masih terbatas diburu dan digunakan para wisudawan sebagai simbol kesuksesan pendidikan/studi yang biasa dipajang di rumah. Proses pembuatan boneka wisuda oleh "Fisma Art" membutuhkan dana modal yang ditalangi melalui program PPK FKIP UNCP pada awal perintisannya, kemudian telah sukses mandiri dengan modal dari omzet yang sudah cukup dikelola pada kelanjutan usaha ini.
"Fisma Art" hanya membutuhkan bahan dan peralatan yang digunakan cukup sederhana.

Boneka wisuda hasil kerajinan tenant ini bisa dari bahan/kain limbah yang digunakan sebagai pakaian boneka, dan membuat kepala boneka yang menggunakan karton ataau kayu dicat dalam bentuk karakter sosok wisudawan dan wisudawati yang diminati. Bahan boneka "Fisma Art" buatan tangan alat dan bahan sementara itu, lebih memilih bahan utama kain, terutama kain fanel. Untuk menarik pelanggang, "Fisma Art" menambahkan hiasan dan aksesori tambahan ke boneka wisuda. Sebagai wawasan informasi pembuatan boneka wisuda, yang selalu diharapkan mampu menginspirasi bisnis tenant. 
Caradde: Jurnal Pengabdian Kepada Masyarakat Vol 1 No 1, Agustus 2018
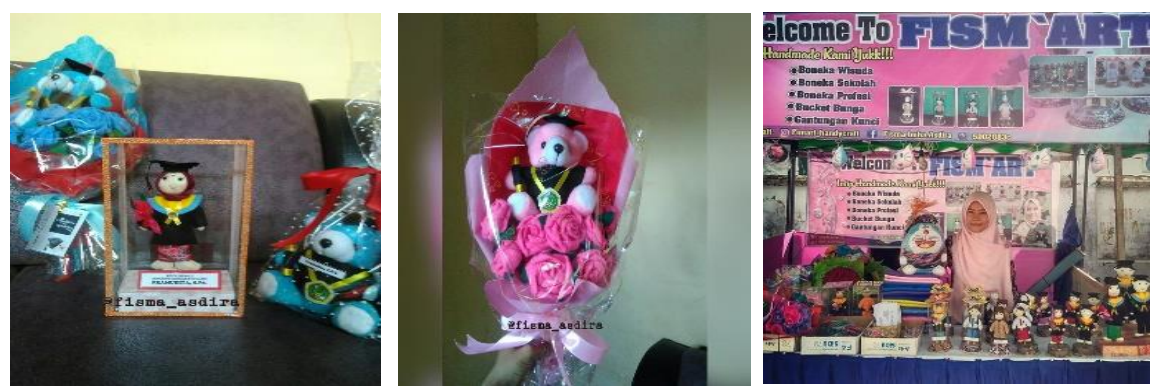

Gambar 3: Boneka Wisuda dan Bucket Bunga "Fisma Art"

Program PPK FKIP UNCP membina saudara Rika dan Karpiyanti membuat bros jilbab atau custom lainnya dari bahan bekas. Anyaman atau rajukan kreatif tenant ini, sampah yang berserakan dimana-mana yang menurut kita tidak berguna dan hanya mengganggu pemandangan, akan berharga bagi orang-orang kreatif. Karena Rika bisa menyulapnya menjadi barang yang berharga yang mempunyai nilai jual tinggi. Sentuhan teknologi alumni ini membuat bros dari plastik bekas (baik plastik bungkus kemasan atau barang bekas yang berbahan plastik, dan sejenisnya), yang dilengkapi gunting, peniti bros, lem tembak, rendah kecil dan sedang, kain perca, flannel, jarum dan benang, sendok/cetakan lainnya yang tahan panas, lilin dan korek api, wadah/baskom, dan air dingin/es. Pembuatannya dilakukan dengan langkah demi langkah sehingga terwujud bros yang menarik dan lucu. Qulling paper yang melibatkan kreativitas tenant dalam sebuah kegiatan program PPK FKIP UNCP untuk membuat quilling paper mulai pada menggulung kertas dengan memperhatikan nilai-nilai estetika sehingga menghasilkan karya seni yang indah dan menawan. Teknik dasar cara membuat paper quilling yang wajib diketahui untuk quilling paper community Warpen Aksesoris program PPK FKIP UNCP. Gambaran kegiatan hampir sama dengan origami dimana sebuah kertas dilipat sedemikian rupa hingga menjadi bermacammacam bentuk.
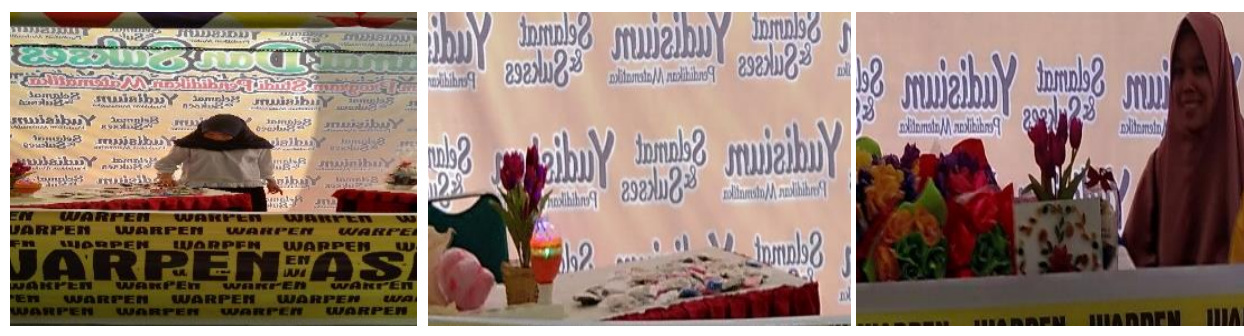

Gambar 4: Jam Akrilik, Lampu Hias, dan Air Mancur

Jam akrilik, Mutmainnah, I Made Kartana Jaya Warpen Aksesoris program PPK FKIP UNCP souvenir yang didesign dengan bentuk miniatur, sebuah akrilik dibentuk dengan minister diprinting, dirangkai dengan dilengkapi jam, lampu bisa warna warni dengan tampilan yang menawan ditambah ornament yang disesuaikan pesanan customer.

Air mancur bola, alternatif penghias rumah/kantor yang asri dan segar tentu dapat menenangkan suasana. Inilah hal sederhana yang menjadi harapan tenant program PPK FKIP UNCP oleh Deborah Tayosuwana yang mewujudkaknnya.
Gemercik air mancur dapat menciptakan irama yang seolah-olah mampu menghilangkan sejenak kepenatan pikiran. Namun, lahan sempit dan harga yang mahal sering menjadi kendala membuat air mancur dalam rumah. Deborah menawarkan hal sederhana tersebut untuk mengatasi masalah atau kendala ini dengan mencoba membuat air mancur dari alat dan bahan yang dipadukan dengan batok kelapa. Sebuah karya Mini Water Fountain oleh Ira Widya memiliki keunikan dan keistimewaan sendiri. Suara air terjun yang dihasilkan Mini Water Fountain ini yang membuat suasana ruangan maupun rumah 
menjadi menentramkan, sangat cocok menjernihkan pikiran yang penat.
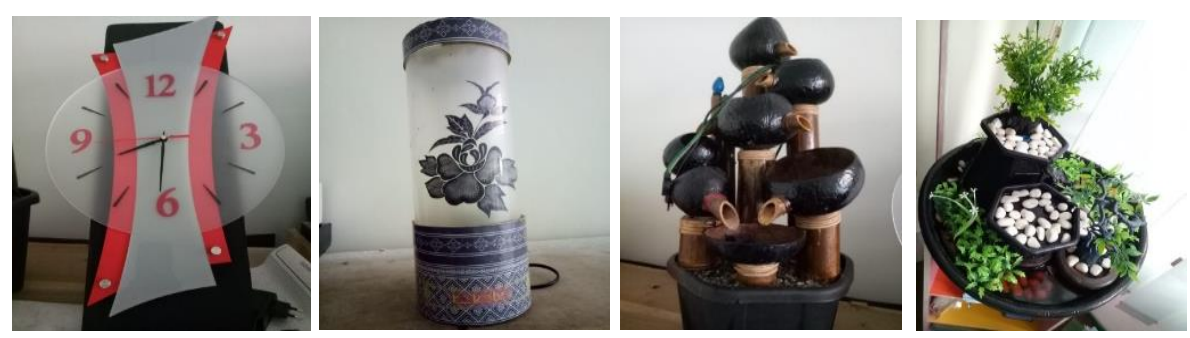

Gambar 5: Brows Bahan Bekas dan Quilling Paper

\section{Warung Pendidikan Bimbingan Belajar}

\section{(WARPEN BIMBEL)}

Jasa Les Matematika (mathematic tutoring) program PPK FKIP UNCP tenant Lis Sugianto menyelenggarakan program belajar matematika dimana seorang siswa diajar/dibimbing oleh tenant Warpen Bimbel matematika, kegiatan belajar mengajar dilakukan di rumah atau lokasi bimbingan belajar mengajar yang didirikan tim program PPK FKIP UNCP. Teknologi (video call, chat, atau video tutorial) sangat mendukung dalam membahas materi tertentu lewat tatap muka atau belajar matematika secara privat secara offline, siswa dapat juga mendapatkan bimbingan belajar secara online dengan berbagai macam sarana tersebut. Hasil belajar siswa penting menjadi perhatian serius, selain respon, aktivitas, dan keterlaksanaan pembelajaran dengan metode pembelajaran matematika guna efektivitasnya yang mempertimbangkan kelebihan dan kekurangan untuk mencapai tujuan Les Privat ini. Les privat disediakan program ini disemua jenjang atau level pendidikan. Inovasi yang ditawarkan Warpen Bimbel program PPK FKIP UNCP "Pendekatan Les Privat Berbasis Lesson Study" dengan tahapan Plan, Do, dan See. Kelebihan pendekatan ini pada faktor pedagogik dan konten konsep pembelajaran dan materi ajar sangat dioptimalkan, sehingga tidak terjadi mal konsep (kesalahan dalam menjelaskan konsep kepada siswa).

English Support memberi kesempatan peserta untuk memilih program yang sesuai tanpa ada tingkatan level yang mengikat (kursus bahasa inggris dengan kesenangan, keakraban, dan kebebasan). English support dikelola sedemikian rupa untuk memahami bahasa Inggris yang terasa mudah dan disukai peserta. Program PPK FKIP UNCP mengembangkan Warpen Bimbel "English Support" sebagai wirausaha menyediakan berbagai macam program kursus mulai dari anak-anak usia 7-13 tahun (SD), remaja usia 14-19 tahun (SMP dan SMA), dan dewasa 20 tahun ke atas

\section{Warung Pendidikan Analisis Data (WARPEN ANDA)}

Ahmad Yogi dan Jasa Olah Data atau Analisis Data di kawasan kampus, tenant program PPK FKIP UNCP menjadi Master Consultan menawarkan analisis data untuk mahasiswa, peneliti, guru, dan siapapun yang membutuhkan analisis data di kawasan kampus dan sekitarnya. Mayani jasa analisis data untuk tingkat pemula dan tingkat lanjut sesuai kebutuhan. Jasa yang melengkapi hasil analisis data dengan interpretasi dari print out, serta diskusi pembahasan dan kesimpulan. Jasa analisis data ini menggunakan aplikasi SPSS terbaru dari IBM, AMOS, Lisrel, Eviews, Excel, Minitab, SAS atau cara manual. Kebutuhan mahasiswa terhadap olah data antara lain untuk penelitian skripsi, tesis atau disertasi. Merintis usaha baru Warpen Analisis Data (Warpen ANDA) untuk kepuasan pelanggan, sebab sebuah jasa atau produk dibeli atau sebagai kebutuhan. Master Consultan memiliki teknisi handal melalui kolaborasi dengan Program Studi Pendidikan Matematika FKIP dan Program Studi Matematika FSAINS yang mumpuni, sehingga usaha ini dapat lebih prospek melayani pelanggan dengan optimal.

\section{Warung Pendidikan Literasi (WARPEN LITERASI)}

Pada tanggal 8 September setiap tahunnya adalah tanggal istemewa, untuk memperingati Hari Literasi Internasional yang ditetapkan oleh UNESCO. Leterasi merupakan kemampuan di dalam membaca dan menulis, tetapi pada program PPK FKIP 
UNCP literasi dikembangkan lebih jauh lagi, yaitu literasi informasi dan komunikasi melalui penyebarluasan terbitan buku sebagai bahan ajar atau bahan bacaan, baik di kawasan kampus maupun di luar kawasan kampus secara universal. Dimulai dari tulisan para dosen wajib ber-ISBN dibolehkan dikelola melalui rintisan usaha "Warpen Literasi" program PPK FKIP UNCP, sekarang ini paling tidak ada belasan buku ajar dosen yang berpotensi bisnis sederhana dalam program ini. Program ini dengan harapan bisa menumbuhkan minat baca peserta didik, sekalipun kenyataannya terbitan buku ajar secara internal masih tergolong minim. Inspirasi bisnis atau usaha ini dalam rangka membantu kampus dan Kemenristekdikti menyukseskan program pemerintah.

\section{Warung Pendidikan Desain (WARPEN DESAIN)}

Desain ujung tombak kemajuan bisnis untuk program PPK FKIP UNCP, untuk memasuki dunia usaha yang semakin ketat. Kehadiran "GEA Design" membantu konsumen dan strategi pasar sebuah produk dan brand. Tenant ini menawarkan sebuah layanan atau produk yang unik dan dipercaya membuat branding \& identity design, print design, dan website solution. "GEA Design" diharapkan menjadi partner desain yang mempunyai kreativitas dan integritas tinggi untuk berkarya, sehingga menghasilkan desain yang baik dan tepat sasaran

\section{Pelaksanaan Pelatihan}

Pelatihan yang dilaksanakan PPK FKIP pada tahun pertama 2018 yaitu (1)
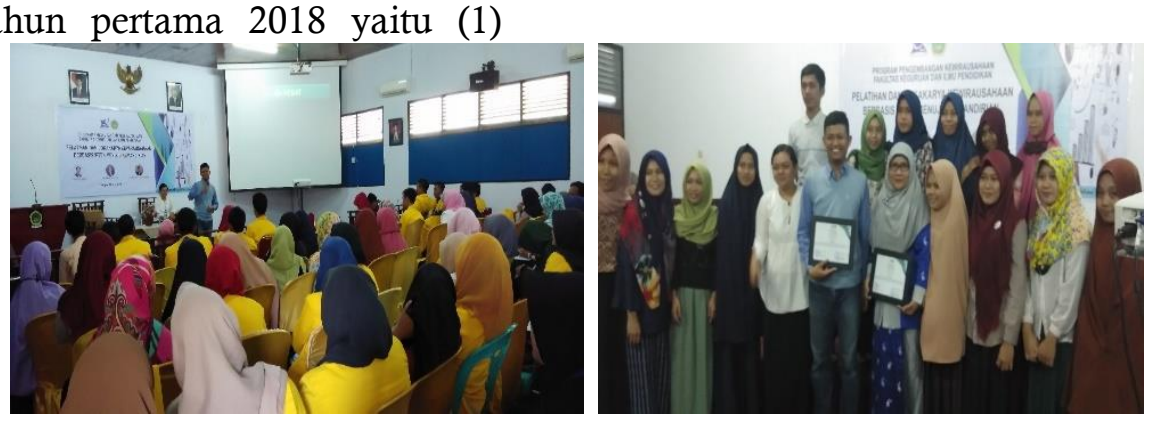

Gambar 6: Pelatihan dan Lokakarya Kewirausahaan

2. Kompetisi Bisnis Plan

Program PPK FKIP UNCP menyelenggarakan bisnis plan pada hari Senin, 2 Juli 2018 yang diikuti oleh pelatihan dan Lokakarya Kewirausahaan berbasis Iptek Menuju Kemandirian sebelum proses rekruitmen calon tenant, (2) Kompetisi Bisnis Plan setelah terpilih tenant, dan (3) pameran Produk Mahasiswa melalui UNCP Expo setelah terpilih tenant

1. Pelatihan dan Lokakarya Kewirausahaan berbasis Iptek Menuju Kemandirian

Program PPK FKIP UNCP menggelar Pelatihan dan Lokakarya Kewirausahaan Berbasis Iptek Menuju Kemandirian di kampus 1 pada tanggal 12 Mei 2018. Dalam pelatihan dan lokakarya ini diisi narasumber kawakan dibidang kewirausahaan dari Himpunan Pengusaha Muda Perguruan Tinggi Sulawesi Selatan. Dihadapan sebanyak kurang lebih 50 orang mahasiswa dan alumni serta dosen pendamping, narasumber mengingatkan dan menegaskan untuk membuka wawasan seluas-luasnya pola pikir mengubah keadaan tidak ada peluang menjadi banyak peluang bisnis dan usaha, dari pengalaman narasumber mengalami kegagalan pada sebuah usaha kemudian membalikkan keadaan menjadi sukses. Hal inilah secara emosional mendorong para bakal tenant berobsesi berbuat banyak dalam arena wirausaha baru dan wirausaha mandiri. Penyelenggaraan pelatihan dan lokakarya diharapkan sebagai fase dari rangkaian program peningkatan kapasitas kewirausahaan tenant nantinya. Termasuk bimbingan teknis pengembangan kewirausahaan untuk mahasiswa dan alumni di perguruan tinggi.

mahasiswa yang memprogram mata kuliah kewirausahaan merupakan bagian dari berbagai program yang diadakan melalui program PPK. Mahasiswa yang ikut serta 
Ma'rufi, Ilyas, Anas, Islamiah. Program Pengembangan

dalam kegiatan ini menyiapkan karya ilmiah sebagai tulisan mengenai perencanaan bisnis selanjutnya dipresentasikan dalam bentuk fanel kelompok dengan menampilkan karya kreatif dalam bentuk produk masing-masing. Terdapat kurang lebih 20 kelompok mahasiswa yang mengikuti bisnis plan ini.

3. Pameran produk mahasiswa (UNCP

Expo)

Pameran produk dalam UNCP Expo menampilkan karya mahasiswa dan alumni hasil racikan dan olahan tangan-tangan terampil dan kreatif dengan sentuhan teknologi. Pameran pencapaian kompetensi mahasiswa dan alumni ini bagian dari karya belasan program pengabdian kepada masyarakat hibah Kemenristekdikti maupun hibah mandiri/universitas.

\section{SIMPULAN DAN SARAN}

Program PPK FKIP Universitas Cokroaminoto Palopo tahun 2018 mengembangkan model pembinaan kepada tenant melalui pelatihan manajemen usaha, memberikan pengalaman praktis kewirausahaan kepada mahasiswa dengan bekerja pada unit bisnis tenant, berkolaborasi dengan lembaga-lembaga terkait dengan pengembangan kewirausahaan. menghasilkan wirausaha baru sebanyak lima orang, menyelenggarakan pameran produk tenant sebagai wahana promotif guna memperkenalkan ke masyarakat, menguatkan karakter kewirausahaan dikalangan mahasiswa dengan pendekatan iptek kewirausahaan modern dan inovatif. Luaran program PPK di Fakultas Keguruan dan Ilmu Pendidikan tahun 2018 yaitu: (1) publikasi pada jurnal nasional dan seminar nasional, (2) lima wirausaha baru yang berbasis Ipteks, dan (3) buku ajar kewirausahaan.

Saran untuk pembinaan tenant dalam program kewirausahaan pada mahasiswa dapat mengembangkan kegiatan serupa dengan melibatkan pihak swasta untuk keberlanjutan kegiatan mahasiswa.

\section{DAFTAR RUJUKAN}

Adhimursandi, D. (2016). Faktor-faktor yang mempengaruhi niat kewirausahaan. KINERJA, 13(2), 193-210.

Ananda A.V. dan Taufik R.D.A. 2015. Intensi kewirausahaan mahasiswa universitas

Trunojoyo Madura. Universitas

Trunojoyo Madura. Jurnal

Agriekonomika. Vo 4, No 1.

Faltin Günter. 2001. Creating a Culture of Innovative Enterpreneurship. Journal International Bussiness and Economy. Vol.2 Number 1.

Mutia, I. 2004. Sistem Informasi Manajemen Konsep. Perpustakan USU; Universitas Sumatra Utara.

Oki D. 2015. Model Persamaan Struktural Faktor-Faktor yang Mempengaruhi Niat Kewirausahaan Mahasiswa FMIPA UNSRI. Universitas Sriwijaya. Jurnal Matematika Vol. 5 No.1, Juni 2015. ISSN: 1693-1394.

Wanda M. Widyani. 2013. Pentingnya pola Kemitraan dalam Meningkatkan Peran Kinerja Usaha Mikro, Kecil dan Menengah di Jawa Timur Periode 20062011. Universitas Surabaya. Jurnal Calyptra Volume 2 Nomor 2.

Rachmat, M. 2012. Entrepreneur Sebagai Pilihan Karir Mahasiswi Maluku Utara: Peran Efikasi Diri dan kepribadian. Jurnal Inovasi dan kewirausahaan, Volume1 No.3.

Saragih, R. (2017) Membangun Usaha Kreatid, Inovatif, dan Bermanfaat melalui Penerapan Kewirausahaan Sosial. Jurnal Kewirausahaan Volume 3 No.2.

Siswadi, Y. (2014). Analisis Faktor Internal, Faktor Eksternal Dan Pembelajaran Kewirausahaan Yang Mempengaruhi Minat Mahasiswa Dalam Berwirausaha. Jurnal Ilmiah Manajemen dan Bisnis, 13(1).

Kolshorn, R. / Tomecko, J. 1995. Understanding Entrepreneurship and How to Promote It. GTZ /CEFE International. Eschborn. 